\title{
ANALYSIS OF FARMERS' RISK AVERSION IN SOUTHERN BORNO, NIGERIA.
}

\author{
M. A. BWALA and Y. BILA \\ (Received 14 December, 2007; Revision Accepted 26 June, 2008)
}

\begin{abstract}
This study examined risk aversion among farmers in Southern Part of Borno State, Nigeria. The study used mainly primary data collected from one hundred and twenty (120) farmers using structural questionnaire administered using multistage random technique. Tools used for the analyses were descriptive statistics and asymmetry of income distribution of the farmers. Analysis of results revealed that majority of the farmers were males and are above 30 years. It was also discovered that $40 \%, 26 \%$ and $34 \%$ of the farmers had Western education, Koranic (Islamic) and no education respectively. The asymmetry of income revealed that $78.4 \%$ of the respondents were risk averse (Asym. $=$ 0.01 to 1 ), with $5.8 \%$ risk neutral (Asym. $=0.0$ ) and $15.8 \%$ risk proclivity (Asym. $=-1$ to -0.01 ). Among those that had risk proclivity, about $73.7 \%$ were below the age of forty years, with $5.3 \%$ of the number being females. The study recommended that farmers should be educated on risk aversion and its attendant negative effects on decision making.
\end{abstract}

KEY WORDS: risk aversion, asymmetry of income, probability.

\section{INTRODUCTION}

Peasants in developing countries often must cope not only with severe poverty but with high income variability (Dercon, 2002). Consequently they are understandably risk averse (Martin, 1997). Wealthy farmers are less risk averse compared to peasants (Kieran, 2000). The attitude of risk aversion among farmers is an impediment to their economic development. An effective means of improving the wellbeing of farmers is by raising their level of income as well as providing infrastructural development. The diffusion of new production techniques, technologies and developmental programs had been reported to uplift the living conditions of peasants (Russell, 1995). However the prevalence of risk aversion among farmers hinders the achievement of this goal. A farmer is said to be risk averse when he prefers his old production methods and practices above new ones, even though the new techniques have the tendency of improving his average yields (Organization for Economic Cooperation and Development, 2000 [OECD]). Given their economically precarious situation, the preference for tried-and-true production methods by peasants should not surprise economists and policy makers. However it should be a cause for worry, because risk aversion distorts incentives available to farmers. Therefore, this work sought to determine the farmers' socio-economic characteristics, their income expectations and finally measure the level of risk aversion amongst them.

\section{METHODOLOGY}

The study area was Southern Part of Borno State, it lies within Latitude $10^{\circ} 22^{\prime \prime}-11^{\circ} 25^{\prime \prime}$ North and
Longitude $12^{0} 00^{\prime \prime}-14^{0} 00 "$ East (Microsoft, 2007). Crops grown in the area include sorghum, millet, rice, cowpea, groundnuts and maize. The area has a land mass of 22,294 square kilometers (SBADP; Southern Borno Agricultural Development Program, 1987). The duration of the rainy season is between $135-160$ days. The rainfall tends to concentrate in $3-4$ months in a year. About $60 \%$ of the rainfall is in the months of July and August (SBADP, 1987).

The study used primary data obtained through a survey of farmers in Southern Part of Borno State in 2005. The instruments used for data collection were structured questionnaires administered on the farmers. Multistage sampling technique was employed in the selection of a sample of one hundred and twenty (120) farmers. Three stages of selection were carried out; four Local Government Areas were initially selected out of the nine in the area. Subsequently, three villages each were randomly selected out of the four Local Governments picked. Finally ten respondents were sampled from each village, giving a total of 120 respondents. Descriptive statistic using percentages was used to analyze data. The asymmetry of income distribution of the farmers was used to determine the level of their risk aversion (Luigi et al., 2001). Income expectations of the farmers were used for the study. Each farmer reports the minimum $\left(y_{m}\right)$ and maximum ( $y_{M}$ ) income he or she expected to get and the probability of getting less than the midpoint of the distribution, prob[y $\leq$ $\left.\left(y_{M}+y_{m}\right) / 2\right]$. The median of the income distribution was determined using the formula and criteria below, adopted and modified from the work of Luigi et al., (2001). 
a. $\begin{aligned} & M(x)=Y_{\min }+\frac{\left(Y_{\max }-Y_{\min }\right)}{2} \quad \frac{\sqrt{1-2 p_{x}}}{2\left(1-p_{x}\right) \pi} \\ & \text { If; } \quad p_{y}<1 / 2 \text { and } p_{z}<1 / 2 \text { or } p_{y}<1 / 2 \text { and } p_{z}>1 / 2\end{aligned}$

$\begin{aligned} & \text { b. } M(x)=\frac{Y_{\max }-Y_{\min }}{2} \\ & \text { If; } p_{y}=1 / 2 \text { and } p_{z}=1 / 2 \text { or } p_{y}=1 / 2 \text { and } p_{z}<>1 / 2\end{aligned}$

$\begin{aligned} & \text { c. } M(x)=Y_{\max }-\frac{\left(Y_{\max }-Y_{\min }\right)}{2} \sqrt{2(1-\pi) p_{x}} \\ & \text { If } p_{y}>1 / 2 \text { and } p_{z}>1 / 2 \text { or } p_{y}>1 / 2 \text { and } p_{z}<1 / 2\end{aligned}$

where;
$\mathrm{M}(\mathrm{x}) \quad=$ median of income distribution
$Y_{\min } \quad=$ minimum income expected
$Y_{\max }=$ maximum income expected
$\mathrm{P}_{\mathrm{x}} \quad=$ probability of getting the income expected
$\pi \quad=$ probability of not getting the income expected
$\mathrm{p}_{\mathrm{y}} \quad=$ probability of on-farm income
$p_{z} \quad=$ probability of off- farm income

The use of any of the formulae above (i, ii, or iii) for the calculation of the median income was hinged on the probability of the expected income of the individual farmer. However in the criteria for the use of formula (ii), it can be observe that probability for off-farm income can either be greater or less than half $(1 / 2)$. This is because, it was discovered that majority of the farmers do not participate in off-farm enterprises but rather while away their time on leisure because off-farm work is not available. Risk aversion was determined using the formula;

Where;

$$
\operatorname{As}(x)=\frac{M(x)-E(x)}{\operatorname{Sd}(x)} \quad \text { (source: Luigi et al., 2001) }
$$

$$
\begin{aligned}
\text { As }(x) & =\text { Asymmetry of income distribution. } \\
M(x) & =\text { median of income distribution } \\
E(x) & =\text { expectation of income (total) } \\
S d(x) & =\text { standard deviation of income. }
\end{aligned}
$$

According to Hardeker (2000) the appropriate probability to use in decision analysis is the decision maker's subjective probabilities. As such, the rigor of obtaining probabilities of income variation directly from the farmers was adopted. Furthermore the choice of the use of the subjective probability is enhanced by its suitability and reliability over an objectively developed probability (Savage, 1957). The probability was developed by asking respondents to state, on a scale from 0 - 100, their chances of getting an amount less or higher than the mid-point of their income expectations in the 12 months following the interview; with values closer to 100 indicating greater certainty of stable future income and less than 50 indicating lower certainty. Asymmetry of income was expected a priori to range from minus one (1 ) to one (1) (Caballero, 1990; Lise, 1997). If $\mathrm{As}(\mathrm{x})$ is greater than zero the distribution is skewed to the right.
Values of asymmetry of income ranging from (0.01) to (0.5) were regarded as moderate risk aversion and (0.6) to (1.0) as high risk aversion. Zero (0) value of asymmetry of income was regarded as risk neutral. If As $(x)$ is less than zero the distribution is skewed to the left. Values ranging from $(-0.01)$ to $(-0.5)$ were considered as moderate risk takers (risk proclivity), ($0.6)$ to (-1) as high risk takers (risk proclivity). Intuitively, individuals who disliked negative income shocks were expected to participate in activities with positive As(x). Risk aversion is associated with distributions that are skewed to the right (Luigi et al., 2001).

\section{RESULT AND DISCUSSION}

Analysis revealed that $90.8 \%$ of the respondents were males while $9.2 \%$ were females (see table 1 ). This 
indicates that majority of the household heads are men. Furthermore it was observed that $20 \%, 78 \%$ and $2 \%$ of the respondents' age were within the range of 18-30, 3160 and above 60 years respectively (See table 1). This indicates that majority of the household heads fell within the age range of 31 to 60 years, followed by 18 to 30 years. Following that majority of the respondents are above 30 years of age, it was considered a bad sign for agriculture, as men within this age group $(18-30)$, are expected to be the major contributors of agricultural labor supply. From the result it was also observed that $85 \%$ of the respondents were married, while $15 \%$ were single (see table 1). This indicates that majority of the household heads were married, while just a few were single. Result further revealed that $36 \%, 32 \%, 15 \%$ and $2 \%$ of the respondents had one, two, three and four wives respectively; while $15 \%$ are single (see table 1 ).

Table 1. Socio-economic characteristics of respondents

\begin{tabular}{lcc}
\hline Socio-economic characteristics & Number of Respondents & Percent \\
\hline Gender & 109 & 90.8 \\
Female & 11 & 9.2 \\
Male & & \\
Age & 24 & 20 \\
$18-30$ & 94 & 78 \\
$31-60$ & 2 & 2 \\
Above 60 & 102 & 85 \\
Marital status & 18 & 15 \\
Married & & \\
Single & 43 & 36 \\
Number of wives & 38 & 32 \\
1 & 18 & 15 \\
2 & 3 & 2 \\
3 & 18 & 15 \\
4 & & \\
Non & 49 & 41 \\
Family size & 61 & 51 \\
$1-6$ & 10 & 8 \\
$7-15$ & & \\
$16-25$ & 16 & 13 \\
Educational qualification & 25 & 21 \\
Primary & 7 & 6 \\
Secondary & 31 & 34 \\
Tertiary & 41 & \\
Koranic & & \\
No formal education & &
\end{tabular}

This indicates that majority of the household heads are polygamous while a sizable number are monogamous. It was also revealed that $41 \%, 51 \%$ and $8 \%$ of the households' sizes ranged within 1-6, 7-15 and 16-25 people in a family respectively (see table 1). With a majority of the farmers been polygamous, family size of the farmers in the area was relatively large. Large family size could be an advantage, when labor supply to diversify income source is considered, furthermore as a result of income diversification, family wealth is endowed. However larger family size creates greater consumption and demand to meet sustenance.

On education it was revealed that $13 \%, 21 \%$ and $6 \%$ of the respondents have undergone primary, secondary and tertiary education respectively. Furthermore, 26\% have undergone Koranic training and $34 \%$ have had no education (see table 1). This indicates that majority of the farm household heads interviewed have had formal education (66\%). Among the household heads who have had formal education, those who had Koranic education were the majority. Followed by those who have had secondary education and who stopped at the primary school level; Those who had tertiary education were the least. The implication of this result was that, farm households with heads that are educated $(66 \%)$ will be readily inclined to scientific and technical knowledge, and as such when enlightened on developmental issues, the rate at which they will comprehend and adapt, will be faster than their counterparts that are not educated. Consequently those that were not educated $(34 \%)$ will be reluctant to embrace new ideas or might do so with the wrong perception.

It was also revealed that $38.3 \%, 44.2 \%$, and $10 \%$ of the respondents expected on-farm income between the ranges of $\mathrm{N1}, 000-\mathrm{N} 50,000$, $\mathrm{N} 51,000$ -

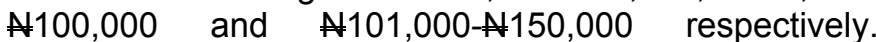
Furthermore, $4.2 \%, 2.5 \%$ and $0.8 \%$ of the respondents

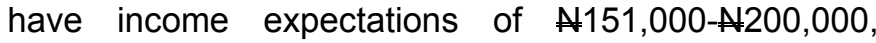
N201,000- $\$ 250,000$ and $\$ 251,000-\quad \$ 300,000$ respectively (see table 2 ). This indicates that majority of the households expect on-farm income within the range

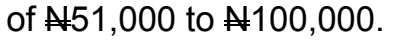


Table 2. Expected annual on-farm income of respondents

\begin{tabular}{lcc}
\hline On-farm income (in Naira) & Number of Respondents & Percent \\
\hline N1,000 - N50,000 & 46 & 38.3 \\
N1,000 - N100,000 & 53 & 44.2 \\
N101,000 - N150,000 & 12 & 10 \\
N151,000 - N200,000 & 5 & 4.2 \\
N201,000 - N250,000 & 3 & 2.5 \\
N251,000 - N300,000 & 1 & 0.8 \\
\hline Total & 120 & 100 \\
\hline Source: Field Survey 2005. & &
\end{tabular}

A sizable number of the respondents also expect on-farm income within the range of 1,000 to $\mathrm{N} 50,000$. Furthermore it was discovered that $21.7 \%$ of the respondents expect no off-farm income however,
$51.7 \%, 22.5 \%, 2.5 \%$ and $1.6 \%$ of the respondents expect off-farm income within the range of $\mathrm{N1} 1,000$ $\mathrm{N} 50,000, \mathrm{~N} 51,000-\mathrm{N} 100,000, \mathrm{~N} 101,000-\mathrm{N} 150,000$ and N151,000-N200,000 respectively (see table 3 ).

Table 3. Annual off/non-farm income of respondents

\begin{tabular}{lcc}
\hline Income & Number of respondents & Percent \\
\hline No income expected & 26 & 21.7 \\
N1000 - N50,000 & 62 & 51.7 \\
N51,000 - N100,000 & 27 & 22.5 \\
N101,000 - N150,000 & 3 & 2.5 \\
N151,000 - N200,000 & 2 & 1.6 \\
\hline Total & 120 & 100 \\
\hline Source: Field Survey 2005. & &
\end{tabular}

Analysis using asymmetry of income distribution revealed that $1.7 \%, 10 \%$ and $4.1 \%$ of the respondents were risk averse with asymmetry ranging within the values of $(-1)-(-0.51),(-0.50)-(-0.10)$ and $(-0.09)-(-$ $0.01)$ respectively. Also, $5.8 \%$ had zero value of asymmetry indicating that they were risk neutral. Furthermore $9.2 \%, 63.3 \%, 4.2 \%$ and $1.7 \%$ of the respondents fell within the range of asymmetry 0.01 $0.09,0.10-0.50,0.51-0.9$ and 1 respectively (see table 4).

Table 4. Level of risk aversion of respondents

\begin{tabular}{lll}
\hline As $(\mathrm{x})$ & Number of Respondents & Percent \\
\hline$(-1)-(-0.51)$ & 2 & 1.7 \\
$(-0.50)-(-0.10)$ & 12 & 10 \\
$(-0.09)-(-0.01)$ & 5 & 4.1 \\
0.0 & 7 & 5.8 \\
$0.01-0.09$ & 11 & 9.2 \\
$0.10-0.50$ & 76 & 63.3 \\
$0.51-0.9$ & 5 & 4.2 \\
1 & 2 & 1.7 \\
\hline Total & 120 & 100 \\
\hline Source: Field Survey 2005. \\
As $(\mathrm{x})$; Asymmetry of individual income distribution
\end{tabular}

The maximum value obtained was 1.00 and a minimum of -0.70 , the mean value for the distribution was 0.15 with a median of 0.1 . The results revealed that $5.8 \%$ of the respondents were risk neutral, while $1.7 \%$ and $14.1 \%$ were high and moderate risk takers respectively. Furthermore $72.5 \%$ (majority) of the respondents were moderately risk averse, while $5.9 \%$ were highly risk averse (see table 4). Among those that had risk proclivity, $73.7 \%$ of them were below the age of 40 years, out of which $5.3 \%$ are female. The moderate values of risk aversion means farmers in the area are facing risky situations, as such they would comfortably prefer their old methods of "doing things" than consider new viable ones (Binswanger, 1980; 1981), or prefer to hold onto commodities that are easily liquefiable (Rosenzweig and Wolpin, 1993). The result was consistent with the findings of Sekar and Ramasamy (2001) and Luigi et al. (2001) where they reported that $93 \%$ of the farmers surveyed in their study were risk averse.

\section{CONCLUSION}

Farmers in Southern Borno are moderately risk averse, this was expected, because risk is prevalent in agriculture. As a result they may tend not to readily accept new ideas or do so with the wrong perception. This attitude may further, reduce the limited chance they have of exploring new frontiers that might improve their production methods and subsequently their standard of living. The fact that farmers in the Southern Part of Borno State are risk averse implies that they have had experiences of risk situations. Therefore educating farmers on risk and subsequently, risk aversion and its attendant negative effects on the farmer's decisionmaking ability is paramount. This is because when these farmers are properly educated, they stand better chances of making the right decisions at the right time. Furthermore one of the means of reducing farmers' aversion towards agricultural programs is to have new methods and techniques of production go along with incentives for farmers (Newberry 1989). Mark and James (2001) asserted that the more risk averse a 
farmer is, the more his risk premium reduces, with increased incentives (Deaton and Case 1998). Therefore by implication farmers will avail themselves to developmental programs or adopt innovations if packaged with benefits such as inputs or source of income. From the foregoing, this study recommends that farmers should be educated on risk aversion and its attendant negative effects on decision making ability. Finally, provision of insurance system that will cushion the losses suffered by farmers will help reduce risk aversion among them.

\section{REFERENCES}

Binswanger, H. P., 1980. Attitudes Towards Risk: Experimental Measurement in Rural India, American Journal of Agricultural Economics 62:3 Pp 395-407.

Binswanger, H. P., 1981. Attitudes Towards Risk . Theoretical Implications of an Experiment in Rural India, Economic Journal 93:3 Pp867-889.

Caballero, R., 1990. Consumption Puzzles and Precautionary Saving. Journal of Monetary Economics Vol.25 No.1 Pp. 11-136.

Deaton, A. and Case, A., 1998. Large Cash Transfers to the Elderly in South Africa, Economic Journal 108,450 Princeton University Pp1330- 1361.

Dercon, S., 2002. Income Risk, Coping Strategy and Safety Nets. The World Bank Research Observer Vol. 17 no.2 Pp.141-166.

Hardaker, J. B., 2000. Some Issues in Dealing with Risk, working paper series in Agricultural Resource Economics, ISNN 14421909.www. Pp.1-18.

Kieran, M. Q., 2000. Production Decisions Under Price Uncertainty for Irish Wheat and Barley producers, Rural Economy Research Center, Teagas 19 Sandmount Avenue, Dublin 4, Pp. 130.

Lise, V., 1997. The Effect of Risk Aversion on Job Matching: Can Differences in Risk Aversion Explain the Wage gap. Department of Economics, lowa University Ames, lowa 50011 515-294-5830.

Luigi, G., Tullio, J. and Luigi, P., 2001. An Empirical Analysis Earnings And Unemployment Risk. The Italian Research Council (CRN) and the Ministry of University Research (MURST) and
Taube Faculty Research Fund at the Stanford Institute for Economic and Policy Research. JEL Classification E21 JEL Classification E21.

Mark, A. D. and James, A. R., 2001. A Correction and Prima Facie Test of The Cononical Theory of Share Tenancy. A Working Paper No. 01-4, Presented to the society of Advancement of Behavioral Economics Biennial Conference, Washington $\mathrm{Pp} 9$.

Martin, U., 1997. The Economics of Tropical Farming Systems. Cambridge University Press. Pp.31, 117.

Microsoft Corporation., 2007. Microsoft $®$ Encarta $\bigodot$, Map of the World. CD ROM.

Newbery, David., 1989. Agricultural Institutions for Insurance and Stabilization, in Pranab Bardhan (ed.) The Economic Theory of Agrarian Institutions, Oxford University Press.

OECD., 2000. Approaches to Income Risk Management in OECD Countries. Directorate for Food, Agriculture and Fisheries Committee for Agriculture. Paper No. AGR/CA/APM/IRM.

Russell, L. L., 1995. Off-farm Labor supply and Fertilizer Use, Paper presented at the Summer Meetings of the American Agricultural Economics Association. Federal Reserve Board, Washington.

Rosenzweig, M. R. and Kenneth, I. W., 1993. Credit Market Constraints, Consumption Smoothening, and the Accumulation of Durable Production Assets in Low Income Countries. Investment Bullocks in India, Journal of Political Economy 101, 2 Pp223-224.

Savage, L. J., 1954. The Foundations of Statistics, Wiley, New York.

SBADP., 1987. Report on the Village Listing Survey of Southern Borno Agricultural Development Project. Prepared by Planning, Monitoring and Evaluation Department Southern Borno Agricultural Development Project Maiduguri, Pp.1-38.

Sekar, I. and Ramasamy, C., 2001. Risk and Resource Analysis of Rain-Fed Tanks in South India. Journal of Economic Development Pp. 1-8. 